\title{
ASSESSMENT OF THE IMPACT OF HARD COMMODITY PRICES CHANGES ON INFLATION IN EUROPEAN UNION COUNTRIES
}

\section{Lapinskaite, I., Miecinskiene, A.}

Indré Lapinskaité, Algita Miečinskienè / Vilnius Gediminas Technical University, Faculty of Business Management, Department of Financial Engineering, Saulètekio al. 11, 10223 Vilnius, Lithuania. Email: indre.lapinskaite@vgtu.It; algita.miecinskiene@vgtu.It.

\begin{abstract}
This article analyses the impact of the changes in hard commodity prices in the world commodity exchanges on the variation of countries' general price level. In other words, this article aims to determine the impact of hard commodity prices changes on inflation. In this paper, all countries of the European Union (EU) are included in the research, and case analysis is done accordingly. The methodology applied is the following: a study of the recent scientific literature, processing and systemization of statistical data, correlation analysis and Granger causality test. The results of the research show that price changes of selected commodities in world commodity exchanges have no absolute dependence on the variation of the general price level in EU countries in the long period. Natural gas should be distinguished, whose price fluctuations in the commodity exchange market show a positive correlation with 14 EU countries' CPI changes. In addition, the research shows that Lithuania's inflation has been affected by all five selected commodities' prices fluctuations. UK and Romanian inflation relate to four of five selected commodities' prices fluctuations.
\end{abstract}

Keywords: general price level; inflation; commodity prices; commodity exchange market, European Union

JEL Classification: E3, E31, Q02, A10, N54, N50, M21

\section{Introduction}

Commodities are produced or extracted by separate industries and are exchanged for one another at world commodity exchanges. In this paper, one type of commodity is selected and analysed - hard commodities, which are typically natural resources that must be mined or extracted from the earth.

The fluctuation of commodity prices is evident in the area of specific fields, such as agricultural economics or transportation (Aiube, 2019). Global commodity trading has also become an essential and important component of investors' portfolios (Yao and Kuang, 2019). For example, like Chen, Qu, Li, and Chen (2019) states, the carbon (coal) market become one of the most promising markets for investors. 
In the last decades, the fluctuation of commodity prices in the world commodity exchanges and its impact on the variation of countries' general price level renewed interest in the subject amongst scientists, economists and other stakeholders. In general, this impact has manifested in the prices of consumer goods increasing relatively faster than income (Grybaite and Stankevičienè, 2018) which in turn induces the fall of monetary value. As purchasing power decreases, so-called inflation appears.

Verheyen (2010) considered that the discussion about the relation between the prices of commodities and inflation started in the 1970s when inflation was high and that in the aftermath the relationship was not as prevalent amongst available data. Nevertheless, in recent decades where inflation has increased and the prices of commodities have several times reached a peak, the discussion has been renewed.

There are many different approaches regarding the correlation between commodity prices and inflation. As the final price in a market mainly depends on the price of materials included in production costs, some analysts see these prices as one of the most influential factors on the inflation rate. Given that much of the materials used in production are either directly commodities or are derived from them, production costs are influenced by the price fluctuation of commodities. However, given that hard commodities in particular (i.e. raw materials) play only a minor role in the production costs of some firms, some analysts do not see as strong an influence of the price fluctuations of commodities on overall production costs.

Still, the price changes of hard commodity prices can greatly influence decision making in businesses, though the extent of this influence depends on the business field and form. Businesses in the import/export field are especially impacted by fluctuating commodity prices in the event that they are tied to fluctuations in inflation. Rising prices can lead to export firms garnering more revenues and importing firms taking a cut.

The following research presented in this article is based on previous research done by the authors (Miečinskienè and Lapinskaitè, 2014), where the case of Lithuania was analysed.

The present research ultimately aims to identify if there is an influence of changes in hard commodities' prices on the general price level in countries. The countries considered here are those in the European Union (EU). The methodology of the research consists of two parts. In the first part, we analyse changes in the price of hard commodities (e.g. oil, natural gas, coal, copper and aluminium) in the world's commodity exchange market. Afterwards, we identify whether or not there is an influence of the price fluctuation of hard commodities on the imbalanced inflation of each EU country. In carrying out the research we focused on data analysis, processing and systemization, and the methods of correlation analysis and Granger causality test were applied.

\section{Discussion about the interaction between inflation and commodities' prices}

As inflation is often accompanied by several economic and social problems such as relative price shifts or a transfer of wealth from lenders to borrowers, defending price stability is a common main goal of economic and social politics (Verheyen, 2010). Cogoljevic, Gavrilovic, Roganovic, Matic, and Piljana (2018) stated that inflation represents an increase in the general price level or a decrease in the value of money and the typical behaviour of 
inflation and inflation transmission process was analysed by Sinicakova, Sulikove, Horvath, Gazda, and Grof (2011), Schwarzer (2018) and Bouchaud, Gualdi, Tarzia, and Zamponi (2017). Additionally, Malliaris (2006) stresses that different measures of inflation exist due to the multiple ways to measure the rate of price increases.

Price stability is commonly understood as an annual increase in the consumer price index (CPI) of around two per cent in the medium term. As it is generally accepted that CPI gives an indication of changes in the cost of living of private households (Martins, 2003), it could be treated as a measurement of the total price changes of the "shopping basket", which represents a typical range of products for any household (Miečinskienè and Ževžikova, 2008). In this paper, the percentage change in CPI is taken as a measurement of inflation.

As the change of the price level has a direct connection to the circulation of assets and income in the whole economy, significant social, political and economic problems may arise when it is challenging to forecast the change of price level. Based on a large body of research, Cekin (2018) emphasised that under certain conditions, fiscal policy also plays an important role in explaining inflation movements and a "dominant" fiscal authority can set the path for the inflation rate. Furthermore, Aftab, Yaseen, and Anwar (2017) and Gerdesmeier (2009) support the opinion that inflation (deflation) has no social consciousness. Nevertheless, it is obvious that inflation (deflation) influences the poorest groups of societies and price stability is seen as a guarantee for safeness. Sometimes there is a need for the intervention of a government on the prices to find a balance between supply and demand in the market. However, from another point of view, state intervention into pricing interferes with the natural forces in the market prices system. While many factors have an influence on price changes, commodity prices are an essential factor not to be overlooked namely due to their role as a main input to production which, in turn, impacts production costs and the final selling price of a product.

The importance of commodity prices fluctuations and the role of commodity prices as one of the causes of inflation has been analysed with varying results in many decades. Frankel (2006) presents a brief description of changes in commodity prices in each decade since the 1970s, during which the prices of oil and other mineral and agricultural products rose. This was followed in the 1980s by gold and other commodity-based standards playing an essential role in all monetary regime decisions. As the prices of commodities declined in the 1990s, this relationship between commodities and monetary regime decisions waned. Fisher and Kumar (2010) generalised the reason for commodity price fluctuations, indicating such factors as extreme uncertainty in both supply and demand, potential political tensions and financial crises.

Kyrtsou and Labys (2006) have stated that any increase in commodity prices could influence inflation, which may be compounded by speculators in a volatile economy. Furthermore, an increase in commodity prices directly influences the profit of a company for reasons already mentioned regarding production costs. In the event of reduced profits, layoffs are to be expected which may lead to higher unemployment rates and, thus, decreased consumption.

There is, nevertheless, still disagreement between scientists, economists, policymakers and other stakeholders about whether or not commodity prices may be attributed as a cause to inflation. Furlong and Ingenito (1996) state that there are several reasons why the prices of 
a commodity could be seen as main indicators for inflation because the prices of commodities react immediately to any of the following economic shocks: changes in demand, decrease in the supply of agricultural products and natural disasters. Additional insight is given into this question by the analysis by Sinicakova (2013) of the level of symmetry among inflation and economic growth shocks.

Building on the aforementioned studies, the International Monetary Fund (2015) and Chiaie, Ferrara, and Giannone (2017) expressed some concerns about the upside risks to price stability due to increased commodity prices. In particular, Chiaie, Ferrara, and Giannone (2017) affirmed that the fluctuation of world commodity prices plays an important role in euro area inflation and all possible risks to price stability. Awokuse and Yang (2003), after analyses of how commodity prices are useful for monetary policy formation, concluded that commodity prices could show the future direction of the economy and Cecchetti and Moessner (2008) stated that the rising commodity prices of recent years have driven inflation higher worldwide. Cecchetti and Moessner (2008), along with Masso and Staeher (2005) and Tully and Lucey (2007), went on to examine the relationship between inflation and commodities and argued that some of the commodity prices vibrations influence inflation only for a short time of period. This was supported by Sekine and Tsuruga (2018) who cited Yellen (2011), who argued that commodity price shocks have only modest and transitory effects on US inflation and that a recent surge of commodity prices do not "warrant any substantial shift in the stance of monetary policy", a finding also shown to be true by Bloomberg and Harris (1995).

Kyrtsou and Labys (2006), in their study, presented the relationship between inflation and commodities as nonlinear and chaotic which was expanded upon by Krichene (2008) who stated that low-interest rates nowadays compared to the period of the 1970s and 1980s, when interest rates were high, can explain why the relation between inflation and commodity prices could be named as weak. Verheyen (2010) and Gaudenzi and Bucciol (2016) emphasized the fact that producers who encounter lower interest rates can deal with higher commodity prices more easily. In other words, in some industrial countries, low inflation could be another reason for a minor influence of commodity price fluctuation on economic performance (De Gregorio, Landerretche, and Neilson, 2007). On a similar note, Saleuddin and Coffman (2018) questioned whether inflation expectations can be measured using future commodity prices and faced controversial results.

However, Ghoshray, Kejriwal, and Wohar (2014) in their work pointed out that many countries are reliant on commodity prices as a source of income and, despite many debates, a strand of theoretical research argues that commodity prices should be stationary. Expanding on that, Ciner (2011) stated that commodities tend to be essential inputs in production and emphasised the use of commodities as speculation hedges and as a factor used by monetary authorities in policymaking as a way of explaining the importance of the relationship between commodity prices and inflation.

The works of the authors analysed in this chapter show that despite aggregated supply and demand, the standard cause of inflation, there are some other important factors influencing inflation, one being commodity prices. Two approaches were analysed, and a conclusion should be made that although commodities are a highly important input element in the costs of final goods and can influence the level of inflation, this level of influence is not defined or clear in terms of both time and geography (i.e. geopolitcally). 


\section{Analysis of the dynamics of hard commodity prices}

Five types of hard commodities, commodities that are extracted from the earth, were chosen to analyse in this paper: coal, natural gas, oil, aluminium and copper. Yearly average data in the period of 2000 and 2018 was used because it better represented the changes in the general price level, which serve as the inflation parameter.

The price of aluminium, an industrial base metal, is directly related to different industries such as transport, construction, and growing demand for residential and business areas. After climbing up to 2.6 dollars per kilo in 2008, aluminium prices fell over 40 per cent in 2009 (Figure 1).

Figure 1 | The price fluctuation of aluminium in $\mathbf{2 0 0 0 - 2 0 1 8}$

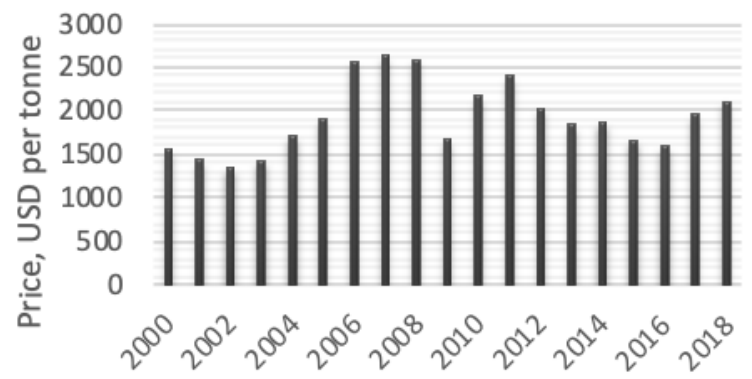

Source: compiled by authors based on Index Mundi, 2019a

This was due to the fact that since the worldwide recession began, the demand for aluminium from main industries fell by a third. Koyfman (2009) distinguishes that overproduction is another force that influenced a sudden decrease in aluminium prices because it encouraged a weighty imbalance of supply and demand. The second price peak is seen in 2011 during the period 2009-2016 and followed by a decrease during the period 2012-2013 (Figure 1). In 2017, aluminium prices rose sharply again and continued to rise in 2018. Metal Miner (2017) explained the reasons as follows: global aluminium demand is more robust than most expected and Chinese stimulus measures boosted demand for aluminium in the auto and real estate industries. Furthermore, the U.S. is expected to demand more aluminium amid Donald Trump's plans to inject one trillion dollars in U.S. infrastructure. Fuller (2019) states that prices appear constrained by high levels of Chinese production of aluminium, in addition to weakening Chinese domestic demand. During 2018, Chinese aluminium production increased by 9.9 per cent, rising to 72.53 million tons.

A similar situation was observed for the prices of copper but on a larger scale. The price of copper increased more than three times in the period 2000-2008 and reached 6963 dollars per ton (Figure 2).

At the end of 2008 and beginning of 2009, the price of copper fell dramatically. One negative macroeconomic influence governing future price direction was declining global economic growth (Reuters, 2008). ABC News (2017) explained that the price for copper from 2009 rose due to Chinese consumption stimulated by their growing economy. Thus, concerns regarding China's economy was the main reason copper prices fell by 7 per cent 
in 2013 (Figure 2). In the aftermath, copper remained one of the worst performing commodities of the next several years until the end of 2016, when copper experienced a sudden spike and, according to Mining (2017), became the best performing commodity in 2017. The rally, which began on the heels of Donald Trump winning in the US presidential election, was partly based on speculation regarding the impact of the President-elect's $\$ 500$ billion infrastructure plans on demand for the metal (Mining, 2017).

Figure 2 | The price fluctuation of copper in 2000-2018

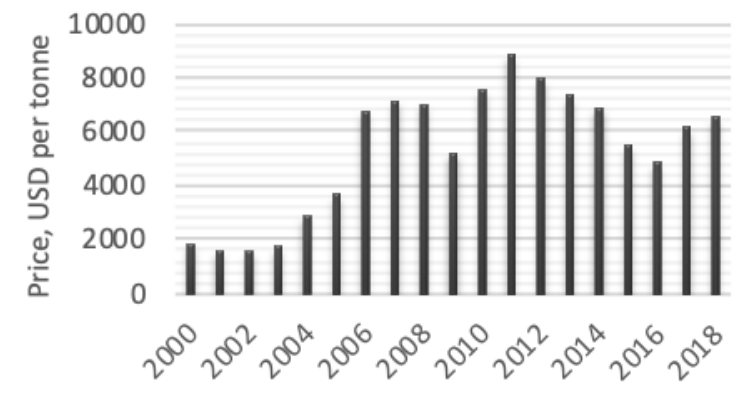

Source: compiled by authors based on Index Mundi, 2019b

Without a doubt, natural gas is a very important energy commodity. Usually, the prices of natural gas are mainly driven by supply and demand, but natural gas prices may also be linked to the price of crude oil and/or petroleum products. In comparing the price dynamics of all the commodities analysed in this research, only the price of natural gas, after a sharp fall in 2009, remained lower than it was in 2000 (Figure 3).

Figure 3 | The price fluctuation of natural gas in $\mathbf{2 0 0 0 - 2 0 1 8}$

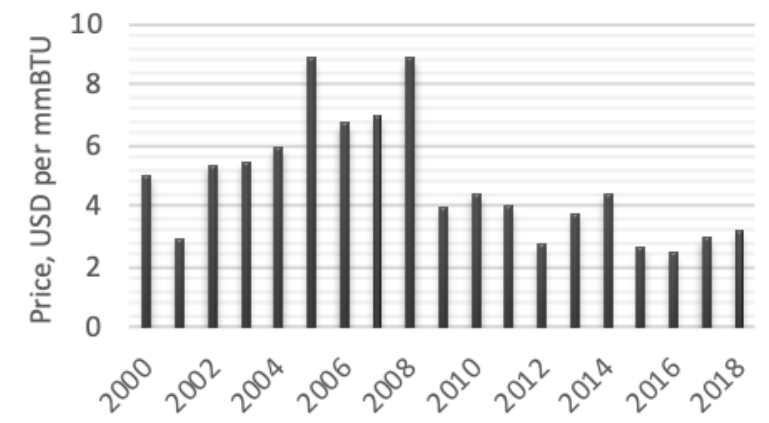

Source: compiled by authors based on Index Mundi, 2019c

In 2017, prices for natural gas spiked again and continued to grow in 2018. Bloomberg (2017) explained the sharp jump of prices as a reaction to concerns about an arctic blast and future winter weather which brought on a relative deficit in natural gas inventory. This surge in perceived demand, along with tight supply, triggered a technical breakout of prices to the upside.

On average, the price of coal grew more than two times between 2000 and 2007 (Figure 4). 
Figure 4 | The price fluctuation of coal in 2000-2018

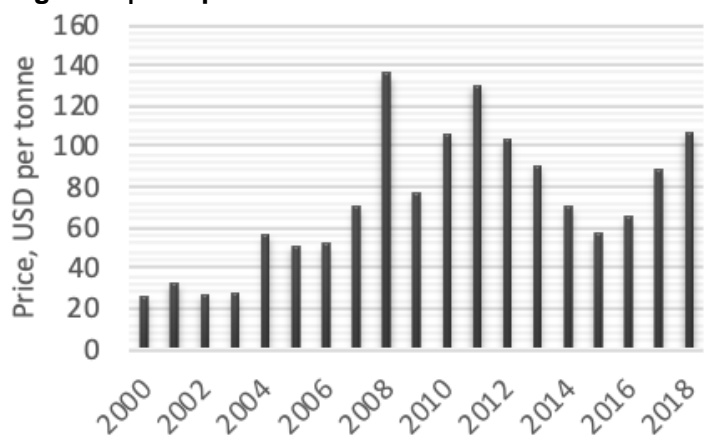

Source: compiled by authors based on Index Mundi, 2019d

In particular, from 2007 to 2008, the price of coal almost doubled. However, the overall fall in prices of energy commodities in 2009 occurred mainly in the coal market where, starting from the third quarter of 2008 to the first quarter of 2009 , the price of coal fell almost 45 per cent from 136 to 77 dollars per ton. Prices peaked again in 2011 before falling again in 2014, which Reuters (2014) attributed to an increase in mining output in an already oversupplied market accompanied by a decrease in demand. The decrease was sustained in 2015 in spite of the fact that coal served as the top fuel used to generate electricity in the world.

Russell (2017) emphasised the reasons for the fluctuation of coal prices in recent years as mainly due to the ongoing debate surrounding the use of coal in comparison to cleaner alternatives. Also, Chen et al. (2019) noted that higher coal prices are connected with the sharp and sustained increase of energy prices overall.

Chen and Bolandifar (2018) named the price of crude oil, one of the most popular and highly valued energy sources, as a perfect example of extreme changes in the price of a commodity. At the beginning of the analysed period, oil prices grew steadily until the second quarter of 2008 when they reached a record of 97 dollars per barrel (Figure 5).

Figure 5 | The price fluctuation of oil in 2000-2018

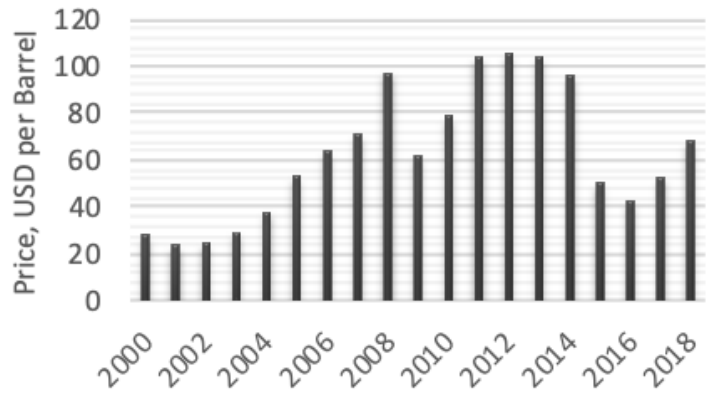

Source: compiled by authors based on Index Mundi, 2019e 
The significant increase in the price of oil in 2008 was caused by its greater use in the global economy overall, especially in the sectors of transport and agriculture. A year later, in 2009, the price of oil decreased by about 40 per cent due to decline in demand and the ongoing economic recession. As the world began to recover from its economic recession in late 2009, the demand of oil began to rise, almost doubling from 61 dollars per barrel in 2009 to more than 100 dollars per barrel in 2011 (Figure 5). The average yearly price of oil remained quite stable for the next three years and fell just slightly to a little less than 100 dollars per barrel in 2014 (Financial Times, 2014). Oil prices started 2015 relatively low and ended the year even lower. According to EIA (2016), this reflected the sustained excess of crude oil supply over global demand. However, despite relatively high U. S. crude oil production, curtailments in production by members of the Organization of the Petroleum Exporting Countries (OPEC) and robust global demand supported crude oil price increases in 2017 (EIA, 2018). Lynch (2019) names that the initial decision by the Saudis, Russians and others to offset potential losses of Iranian oil, along with the Trump Administration's granting of waivers to major Iranian customers, was a major element to this increase. Lynch (2019) also notes that market fundamentals have also played a big role in this increase, especially the unexpectedly strong rise of U. S. shale oil production in 2018.

Summarising the analysis of the changes in commodities' prices for the period of 20002018, we can state that the prices of commodities are sensitive to changes in market conditions. The prices of all analysed commodities increased from $100 \%$ to more than $300 \%$ from 2000 through 2018 and some of the commodities, due to their impending replacement by cleaner alternatives, face the issue of longevity which causes price fluctuations as well. However, the predictions of industry analysts are optimistic stating that the current price momentum is more sustainable than the spike of five years ago, which was driven by shortages caused by the industry's slump during the global financial crisis (ABC News, 2017). The significant changes in commodity prices in world commodity exchanges theoretically could have an impact on price changes of final goods and services, thus changing the rate of inflation in EU countries. Having analysed the dynamics of hard commodity prices and inflation on a global scale, this research now aims to find dependencies of selected hard commodities on the CPI all EU countries.

\section{Identification of the impact of changes in commodity prices on inflation in the EU countries: methodology and the results}

As mentioned in earlier sections, the goal of this research is to identify if there is an influence of the changes in the prices of hard commodities on the general price level, as measured in an inflation parameter, in EU countries over the last 18 years.

The dependence between $\mathrm{Y}$, the rate of inflation of all EU countries as given in the $\mathrm{CPI}$, and selected commodities' prices is identified as: $\mathrm{X}_{1}$ (price of aluminium, dollars per ton); $\mathrm{X}_{2}$ (price of copper, dollars per ton); $\mathrm{X}_{3}$ (price of natural gas, dollars per mmBTU); $\mathrm{X}_{4}$ (price of coal, dollars per ton); $X_{5}$ (price of crude oil, dollars per barrel).

The investigation is done in three steps: 1. Pearson coefficient of correlation is calculated; 2. its significance is estimated; 3 . Granger causality test is carried out. 
To estimate the degree to which variable $\mathrm{Y}(\mathrm{CPI})$ is linearly related to every $\mathrm{X}$ (selected commodities), correlation analysis is used.

Significance of the correlation coefficients is determined from t-statistic. Critical value $t\left(t_{k r}=\right.$ 1.74 ) is found using a statistical function TINV at the level of significance -0.1 and degrees of freedom -17 (i.e. 19-2). When $t_{\mathrm{kr}}<\mathrm{t}$, the coefficient of correlation is significant, and a stochastic dependence exists.

In order to investigate if there is causality between analysed variables, the Granger causality test is carried out. The test is based on hypotheses that lagged values of $X_{(t)}$ don't Granger cause the value of $Y_{(t)}$ and lagged values of $Y_{(t)}$ don't Granger cause the values of $\mathrm{X}_{(\mathrm{t}) \text {. }}$

Before the calculations, the analysed time series was transferred to stationary data. To avoid unit roots which could cause unpredictable results in the time series analysis, the Augmented Dickey-Fuller (ADF) test was done. The lengths of lag for each test were selected based on AIC (Akaike Information Criterion).

There are several possible outcomes regarding causality between the variables: one direction having causality, two directions having causality between the two analysed variables, and zero or no causal relationship.

The outcomes are set according to the probability value ( $p$-value). If the $p$-value from the tests' results is less than the significance level of 0.05 , then the null hypothesis can be rejected. Statistical package Eviews is used for the Granger causality test.

The data samples used in this research are annual with a range of 2000 to 2018 . The starting date was chosen due to the movement of commodity prices beginning a consistent rise in that year before reaching records in the middle of 2008. The data analysis tool from Microsoft Excel program was used on the samples and the numerical characteristics of the changes in the investigated commodities' prices are presented in Table 1 and numerical characteristics of $\mathrm{Y}$ are presented in Table 2.

From Table 1, it is seen that the standard deviation of investigated commodities' prices was lower than their arithmetic means. The calculated coefficient of variation shows that during the period, the commodities with the most fluctuated prices were coal, copper and oil. The most moderate price changes were for aluminium.

Table 1 | Numerical characteristics of selected commodity prices

\begin{tabular}{|c|c|c|c|}
\hline Commodities & Mean & $\begin{array}{c}\text { Coefficient of } \\
\text { Variation }\end{array}$ & Standard deviation \\
\hline$X_{1}$ & 1911.57 & 0.22 & 411.73 \\
\hline$X_{2}$ & 5240.56 & 0.47 & 2438.87 \\
\hline$X_{3}$ & 4.85 & 0.41 & 1.995 \\
\hline$X_{4}$ & 70.53 & 0.48 & 33.58 \\
\hline$X_{5}$ & 62.58 & 0.47 & 29.13 \\
\hline
\end{tabular}

Source: compiled by authors

The analysis of the dynamics of the level of inflation in EU countries during the period 20002018 showed that the highest average inflation rate was in Romania (9.84 \%) which is more than double compared to other leading EU countries, followed closely by inflation in 
Hungary $(4.36 \%)$ and Bulgaria (4.19\%) (see Table 2). The lowest average inflation rates were in Sweden (1.28\%), Germany (1.46\%) and France (1.46\%). Assessing the fluctuation of inflation shows that inflation in Ireland and Romania fluctuated most. The smallest variation in inflation was in Austria and Germany.

Table 2 | Numerical characteristics of CPI

\begin{tabular}{|c|c|c|c|}
\hline EU countries & Mean & $\begin{array}{c}\text { Coefficient of } \\
\text { Variation }\end{array}$ & Standard deviation \\
\hline AT & 1.96 & 0.37 & 0.73 \\
\hline $\mathrm{BE}$ & 2.01 & 0.53 & 1.07 \\
\hline$B G$ & 4.19 & 0.90 & 3.78 \\
\hline $\mathrm{CY}$ & 1.69 & 1.16 & 1.96 \\
\hline $\mathrm{CZ}$ & 2.20 & 0.72 & 1.59 \\
\hline $\mathrm{DE}$ & 1.46 & 0.45 & 0.65 \\
\hline DK & 1.70 & 0.54 & 0.92 \\
\hline EE & 3.40 & 0.77 & 2.63 \\
\hline ES & 2.17 & 0.68 & 1.48 \\
\hline $\mathrm{FI}$ & 1.56 & 0.79 & 1.23 \\
\hline FR & 1.46 & 0.54 & 0.78 \\
\hline GR & 2.01 & 0.99 & 2.00 \\
\hline $\mathrm{HR}$ & 2.19 & 0.80 & 1.74 \\
\hline $\mathrm{HU}$ & 4.36 & 0.66 & 2.86 \\
\hline $\mathrm{IE}$ & 1.92 & 1.33 & 2.55 \\
\hline IT & 1.79 & 0.58 & 1.03 \\
\hline LT & 2.42 & 1.14 & 2.76 \\
\hline LU & 2.05 & 0.47 & 0.97 \\
\hline LV & 3.71 & 1.07 & 3.97 \\
\hline MT & 2.00 & 0.49 & 0.970 \\
\hline $\mathrm{NL}$ & 1.83 & 0.51 & 0.94 \\
\hline $\mathrm{PL}$ & 2.55 & 0.99 & 2.52 \\
\hline PT & 1.99 & 0.72 & 1.44 \\
\hline $\mathrm{RO}$ & 9.84 & 1.24 & 12.19 \\
\hline SE & 1.28 & 0.87 & 1.11 \\
\hline SI & 3.16 & 0.88 & 2.79 \\
\hline SK & 3.56 & 0.93 & 3.31 \\
\hline UK & 2.05 & 0.54 & 1.10 \\
\hline
\end{tabular}

Source: compiled by authors based on Eurostat, 2019

The results of the correlation analysis between CPI and the prices of commodities are presented in Table 3. Statistically dependent values are bolded in Table 3. 
Table $3 \mid$ The coefficients of correlation

\begin{tabular}{|c|c|c|c|c|c|}
\hline \multirow[b]{2}{*}{ EU countries } & \multicolumn{5}{|c|}{ Commodities } \\
\hline & aluminium & copper & natural gas & coal & oil \\
\hline AT & 0.40 & 0.15 & 0.36 & 0.38 & 0.33 \\
\hline $\mathrm{BE}$ & 0.42 & 0.11 & 0.39 & 0.41 & 0.17 \\
\hline$B G$ & 0.34 & -0.23 & 0.65 & -0.04 & -0.15 \\
\hline $\mathrm{CY}$ & 0.25 & -0.21 & 0.59 & 0.02 & -0.10 \\
\hline $\mathrm{CZ}$ & 0.35 & -0.03 & 0.37 & 0.22 & 0.06 \\
\hline $\mathrm{DE}$ & 0.56 & 0.19 & 0.47 & 0.34 & 0.29 \\
\hline DK & 0.27 & -0.09 & 0.43 & 0.16 & 0.05 \\
\hline $\mathrm{EE}$ & 0.58 & 0.13 & 0.57 & 0.34 & 0.20 \\
\hline ES & 0.28 & -0.24 & 0.59 & $\begin{array}{l}-0.06 \\
\end{array}$ & -0.13 \\
\hline $\mathrm{FI}$ & 0.45 & 0.20 & 0.27 & 0.35 & 0.34 \\
\hline FR & 0.31 & -0.11 & 0.58 & 0.14 & 0.03 \\
\hline GR & 0.25 & -0.24 & 0.58 & -0.02 & -0.20 \\
\hline $\mathrm{HU}$ & 0.04 & -0.39 & 0.31 & -0.21 & -0.31 \\
\hline HR & 0.34 & -0.08 & 0.57 & 0.12 & 0.10 \\
\hline IE & 0.12 & -0.36 & 0.45 & -0.34 & -0.28 \\
\hline IT & 0.21 & -0.17 & 0.43 & 0.08 & 0.00 \\
\hline LT & 0.74 & 0.46 & 0.51 & 0.64 & 0.46 \\
\hline LU & 0.42 & 0.02 & 0.48 & 0.19 & 0.13 \\
\hline LV & 0.61 & 0.10 & 0.80 & 0.27 & 0.15 \\
\hline MT & 0.28 & -0.11 & 0.55 & 0.19 & 0.03 \\
\hline $\mathrm{NL}$ & -0.18 & -0.33 & 0.06 & -0.12 & -0.10 \\
\hline $\mathrm{PL}$ & -0.01 & -0.26 & 0.14 & -0.02 & -0.13 \\
\hline PT & 0.09 & -0.33 & 0.29 & -0.20 & -0.29 \\
\hline $\mathrm{RO}$ & -0.43 & -0.72 & 0.09 & -0.58 & -0.58 \\
\hline SE & 0.37 & 0.01 & 0.28 & 0.23 & -0.01 \\
\hline $\mathrm{SI}$ & -0.26 & -0.65 & 0.29 & -0.44 & -0.49 \\
\hline SK & -0.20 & -0.59 & 0.27 & -0.42 & -0.44 \\
\hline UK & 0.72 & 0.69 & 0.25 & 0.82 & 0.73 \\
\hline
\end{tabular}

Source: compiled by authors

As evidenced in Table 3, most of the coefficients of correlation do not show a statistical relationship between the selected hard commodities and inflation in EU countries. However, the changes in prices of gas $\left(X_{3}\right)$ show positive correlation in 14 countries, aluminium $\left(X_{1}\right)$ correlation in 10 countries (9 positive and 1 negative), coal $\left(X_{4}\right)$ correlation in 6 countries ( 3 positive and 3 negative), copper $\left(\mathrm{X}_{2}\right)$ correlation in 5 countries (2 positive and 3 negative) 
and oil ( $\left.X_{5}\right)$ correlation in 5 countries ( 3 negative and 2 positive). The correlation appearance varies between $0 \%$ and $36 \%$ in all 28 countries and is a significantly low ratio. This indicates that it is not reasonable to say that changes in the prices of commodities have an impact on inflation over a long period of time.

The results of the research demonstrated that, overall, changes in the prices of commodities in world commodity exchanges have no dependence on the general price level in EU countries, with the exception of Lithuania, Romania, UK, Slovakia and Slovenia, the countries that have the highest number of correlations between commodity prices and inflation.

The Granger causality test was carried out to determine if there is causality between commodity prices and inflation. The countries having the highest number of correlated variables were selected for the research. The null hypotheses were $(\mathrm{H} 0)$ :

- Commodity price does not Granger cause inflation,

- Inflation does not Granger cause commodity price.

The lengths of lags vary from 0 to 2 and were selected for each pair of hypotheses individually based on AIC (Akaike Information Criterion). The results of the Granger causality test are presented for each country separately and the outcomes are set according to the probability value ( $p$-value) (Annex 1).

All the results indicate no causality at all, with the exception of one direction causality case in the UK where the null hypothesis, NATURAL GAS $\left(\mathrm{X}_{3}\right)$ does not Granger Cause INFLATION (Y), can be rejected, thus implying that natural gas causes inflation in the UK.

The divergent nature of these results with the initial correlation observations makes it difficult to determine if there is a definite link between the prices of commodity prices in EU countries and inflation over a long period of time. In order to determine the cause of the obtained results, it would be appropriate to carry out further research by including other types of commodities in the analysis, selecting different countries and utilizing the producer price index (PPI) over $\mathrm{CPI}$ as an inflation indicator.

\section{Conclusion}

From a theoretical point of view, there are several factors influencing inflation, one of which is the price of commodities. This paper analysed two approaches to the influence of commodity prices on inflation and the conclusion should be made that while the prices of commodities can be tied to the level of inflation, the level of this influence is not clear in terms of both time or geography.

Several analytical opinions should be highlighted regarding the variations of commodity prices in world commodity exchanges and their impact on inflation and the influence of governments into this pricing. Furthermore, the role of producers, which can face lower interest rate costs or reduce their margins instead of raising prices as a means of coping with higher commodity prices, should also be considered.

The investigation of the level of inflation and its dynamics in EU countries during the period 2000-2018 showed that the highest average inflation rate was in Romania (9.84\%), followed by Hungary $(4.36 \%)$ and Bulgaria $(4.19 \%)$. The lowest average inflation rates 
were in Sweden (1.28\%), Germany and France (1.46\%). Assessing the fluctuation of inflation shows that inflation in Romania and Latvia fluctuated the most and the least in Germany and Austria.

The investigation shows the increase of almost all commodity prices which were analysed in this research. The growth varies from $100 \%$ to more than $300 \%$ from 2000 through 2018. The calculated coefficient of variation shows that during the period analysed, the commodities with the most volatile fluctuation in prices were copper, oil and coal. The lowest price changes were for aluminium.

The results of the research show that variation of the general price level in EU countries has no linear dependence on the changes of selected commodity prices in world commodity exchanges over the long run. In analysing the results, natural gas should be distinguished, whose price fluctuations in the commodity exchange market show a positive correlation with 14 EU countries' CPI changes. In addition, the research shows that Lithuania's inflation was affected by all five of the selected commodities' price fluctuations and inflation in the UK and Romania had a relation with four of the five selected commodities' prices fluctuations. Nevertheless, this was not enough to conclude that change in commodity prices have a long-term impact on inflation, which was further supported in the results of the Granger causality tests which diverged from the initial correlation observations.

To identify and ascertain the reason for the results, another research including different types of commodities, selecting different countries and using a different inflation indicator would be advised.

\section{References}

ABC News (2017). Wool back in fashion, pushing prices to record highs. Retrieved September 30, 2019, from http://www.abc.net.au/news/2017-01-18/wool-back-in-fashion-pushing-pricestowards-record-highs/8191458.

Aftab, S., Yaseen, M. R., \& Anwar, S. (2017). Impact of rising food prices on consumer welfare in the most populous countries of South Asia. International Journal of Social economics, 44(8), 10621077.

Aiube, F. A. L. (2019). On the Brazilian fuel pricing policy: a Gaussian factor model approach. Applied Economics, 1-12. https://doi.org/10.1080/00036846.2019.1659929.

Awokuse, T., \& Yang, J. (2003). The Informational Role of Commodity Prices in Formulating Monetary Policy: A Reexamination. Economics Letters, 79(2), 219-224.

Bloomberg (2019). Natural Gas Prices are on a Tear. Retrieved October 2, 2019, from https://www.bloomberg.com/view/articles/2017-11-13/natural-gas-prices-are-on-a-tear.

Bloomberg, S. B., \& Harris, E. S. (1995). The Commodity-consumer Prices Connection: Fact or Fable? Economic Policy Review, 1(3), 21-38.

Bouchaud, J. P., Gualdi, S., Tarzia, M., \& Zamponi, F. (2017). Optimal Inflation Target: Insights from an Agent-based Model. Economics: the Open Access Open-Assessment E-Journal, 12(2018-15), 1-27.

Cecchetti, S. G., \& Moessner. R. (2008). Commodity Prices and Inflation Dynamics. BIS Quarterly Review. Retrieved from https://www.bis.org/publ/qtrpdf/r_qt0812f.htm. 
Cekin, S. E. (2018). Inflation Targeting, Fiscal Policy, and the Exchange Rate Regime. Emerging Markets Finance \& Trade, 54(9), 2093-2116.

Chen, Y., Qu, F., Li, W., \& Chen, M. (2019). Volatility Spillover and Dynamic Correlation Between the Carbon Market and Energy Markets. Journal of business economics and management, 20(5), 979-999.

Chen, Z., \& Bolandifar, E. (2018). Hedging through Index-based Price Contracts in Commodity-based Supply Chains. Omega. doi: https://doi.org/10.1016/j.omega.2018.10.006

Chiaie, S. D., Ferrara, L., \& Giannone D. (2017). Common factors of commodity prices (European Central Bank Working paper series). Retrieved from https://www.ecb.europa.eu/pub/pdf/scpwps/ecb.wp2112.en.pdf?b5182c4253e738608925a443 ebcdd409

Ciner, C. (2011). Commodity prices and inflation: Testing in the frequency domain. Research in International Business and Finance, 25(3), 229-237.

Cogoljevic, D., Gavrilovic, M., Roganovic, M., Matic, I., \& Piljana, I. (2018). Analyzing of consumer price index influence on inflation by multiple linear regression. Physica A: Statistical Mechanics and its Applications, 505, 941-944.

De Gregorio, J., Landerretche, O., \& Neilson, C. (2007). Another Pass-Through Bites the Dust? Oil Prices and Inflation. (Central Bank of Chile Working Papers No. 417). Retrieved from http://si2.bcentral.cl/public/pdf/documentos-trabajo/pdf/dtbc417.pdf.

EIA (2019a). Crude oil prices started 2015 relatively low, ended the year lower. Retrieved October 4, 2019, from https://www.eia.gov/todayinenergy/detail.php?id=24432.

EIA (2019b). Crude oil prices increased in 2017, and Brent-WTI spread widened. Retrieved October 4, 2019, from https://www.eia.gov/todayinenergy/detail.php?id=34372.

Eurostat (2019). HICP - inflation rate. Retrieved August 24, 2019, from https://ec.europa.eu/eurostat/tgm/table.do?tab=table\&init=1\&language=en\&pcode=tec00118\&p lugin $=1$

Financial Times (2019). US oil Price Hits 2014 High Above 100\$. Retrieved October 2, 2019, from http://www.ft.com/cms/s/0/5bb450f6-9281-11e3-9e43-00144feab7de.html\#axzz33qo5pU85.

Fisher, B., \& Kumar, A. (2010). The right way to hedge. Retrieved from http://www.mckinsey.com/ business-functions/strategy-and-corporate-finance/our-insights/the-right-way-to-hedge.

Frankel, J. A. (2006). The effect of monetary policy on real commodity prices (National Bureau of Economic Research Working Paper No. 12713). Retrieved from https://www.nber.org/papers/w12713.

Fuller, B. (2019). Aluminum MMI: Aluminum Prices Decline While Monthly Index Gains 2.3\%. Retrieved September 18, 2019, from https://agmetalminer.com/2019/03/07/aluminum-mmi-aluminumprices-decline-while-monthly-index-gains-2-3/

Furlong, F., \& Ingenito, R. (1996). Commodity prices and inflation. FRBSF Economic Review, 2, 27-46.

Gaudenzi B. \& Bucciol, A. (2016). Jet fuel price variations and market value: a focus on low-cost and regular airline companies. Journal of Business Economics and Management, 17(6), 977-991.

Gerdesmeier, D. (2009). Stability of Prices: Why is that importantly for you? Retrieved from https://www.ecb.europa.eu/pub/pdf/other/whypricestability_en.pdf.

Ghoshray, A., Kejriwal, M., \& Wohar, M. E. (2014). Breaks, trends and unit roots in commodity prices: a robust investigation. Studies in Nonlinear Dynamics \& Econometrics, 18(1), 23-40. 
Grybaitè, V., \& Stankevičienè. J. (2018). An empirical analysis of factors affecting sharing economy growth. Oeconomia Copernicana, 9(4), 635-654.

Index Mundi (2019a). Aluminum. Retrieved August 25, 2019, from http://www.indexmundi.com/commodities/?commodity=aluminum\&months=60.

Index Mundi (2019b). Copper. Retrieved August 25, 2019, from http://www.indexmundi.com/commodities/?commodity=copper\&months=60.

Index Mundi (2019c). Natural Gas. Retrieved August 25, 2019, from http://www.indexmundi.com/commodities/?commodity=natural-gas\&months=60.

Index Mundi (2019d). Coal. Retrieved August 25, 2019, from http://www.indexmundi.com/commodities/?commodity=coal-australian\&months $=60$.

Index Mundi (2019e). Crude Oil (petroleum). Retrieved August 25, 2019, from http://www.indexmundi.com/commodities/?commodity=crude-oil\&months=60.

International Monetary Fund (2015). World Economic Outlook. Retrieved from file://C:/Users/690/Downloads/_textpdf.pdf.

Koyfman, A. (2009). Aluminum Price Outlook. Retrieved September 6, 2019, from http://www.wealthdaily.com/articles/aluminum-price-outlook/2111.

Krichene, N. (2008). Recent Inflationary Trends in World Commodities Markets (IMF Working Paper No. WP/08/130). Retrieved from https://www.imf.org/external/pubs/ft/wp/2008/wp08130.pdf.

Kyrtsou, C., \& Labys, W. C. (2006). Evidence for chaotic dependence between US inflation and commodity prices. Journal of Macroeconomics, 28(1), 256-266.

Lynch, M. (2019). What Happened to Oil Prices in 2018? Retrieved October 4, 2019, from https://www.forbes.com/sites/michaellynch/2019/01/02/what-happened-to-oil-prices-in2018/\#72d96b936d83

Malliaris, A. G. (2006). US inflation and commodity prices: Analytical and empirical Issues. Journal of Macroeconomics, 28(1), 267-271.

Martins, J. H. (2003). Minimum Living Level and Consumer Price Index: what's in a name? Development Southern Africa, 20(2), 197-212.

Masso, J., \& Staeher K. (2005). Inflation dynamics and nominal adjustment in the Baltic States. Research in International Business and Finance, 19(2), 281-303.

Metal Miner (2017). 3 Reasons Why Aluminum Prices Will Rise in 2017. Retrieved August 28, 2019, from https://agmetalminer.com/2017/01/17/3-reasons-why-aluminum-prices-will-rise-in-2017.

Miečinskienè, A., \& Lapinskaitè, I. (2014). The research on the impact of the changes of commodity price level in the world commodity exchanges on variation of general price level. Journal of Scientific Papers Economics \& Sociology, 7(3), 71-88.

Miečinskienè, A., \& Ževžikova, O. (2008). Price level changes of the key consumption product groups. In 5th international scientific conference "Business and management' 2008": selected papers. Vilnius, Lithuania.

Mining (2019). Copper to be best performing commodity of 2017 - analysts. Retrieved September 30, 2019, from http://www.mining.com/copper-best-performing-commodity-2017-analysts/.

Reuters (2008). Copper price volatility seen high in 2008/09 - CPM. Retrieved September 30, 2019, from http://www.reuters.com/article/2008/05/10/copper-conference-idUSN1065788520080510. 
Reuters (2014). Thermal coal prices to drop further on oversupply. weak demand. Retrieved September 30, 2019, from http://in.reuters.com/article/2014/03/20/energy-coal-pricesidINL6N0MH30Y20140320.

Russell, C. (2017). Coal, a scarce commodity? Retrieved October 2, 2019, from http://www.thehindu.com/business/Industry/coal-a-scarce-commodity/article19944886.ece.

Saleuddin, R. \& Coffman, DM. (2018) Can inflation expectations be measured using commodity futures prices? Structural Change and Economic Dynamics, 45, 37-48.

Schwarzer, J. A. (2018). Cost-Push and Demand-Pull Inflation: Milton Friedman and the "Cruel Dilemma". Journal of economic perspectives, 32(1), 195-210.

Sekine, A. \& Tsuruga, T. (2018). Effects of Commodity Price Shocks on Inflation: A Cross Country Analysis. Understanding Persistent Deflation. Oxford Economic Papers, 70(4), 1108-1135.

Sinicakova, M. (2013). Transmission of inflation and economic growth in the euro area in the respect to a single monetary rule. Journal of Applied Economic Sciences, 8(4), 499-509.

Sinicakova, M., Sulikove, V., Horvath, J., Gazda, V., \& Grof, M. (2011). Behaviour of inflation within V4 countries. International Research Journal of Finance and Economics, 70, 59-67.

Tully, E., \& Lucey, B. M. (2007). A Power GARCH examination of the gold market. Research in International Business and Finance, 21(2), 316-325.

Verheyen, F. (2010). Monetary policy, commodity prices and inflation: Empirical evidence from the US (Ruhr Economic Papers \#216). Retrieved https://www.econstor.eu/dspace/bitstream/10419/45303/1/655732020.pdf.

Yao, CZ., \& Kuang, PC. (2019). A study of lead-lag structure between international crude oil price and several financial markets. Physica A: Statistical Mechanics and its Applications, 531. https://doi.org/10.1016/j.physa.2019.121755

Yellen, J. (2011, April 11). Commodity Prices, the Economic Outlook, and Monetary Policy. Retrieved from https://www.federalreserve.gov/newsevents/speech/yellen20110411a.htm.

The research paper has been reviewed. | Received: October 17, 2019; Revised: December 23, 2019; Accepted: January 2, 2020; Prepublished online: January 19, 2020; Published: January 30, 2020 


\section{Annexes}

Annex 1 | Granger causality test results

\begin{tabular}{|c|c|c|c|}
\hline \multicolumn{4}{|l|}{ Lithuania } \\
\hline Null Hypothesis $\left(\mathrm{H}_{0}\right)$ & p-value & Decision for $\mathrm{H}_{0}$ & Outcome \\
\hline $\begin{array}{l}\text { ALUMINIUM }\left(\mathrm{X}_{1}\right) \text { does not Granger } \\
\text { Cause INFLATION }(\mathrm{Y})\end{array}$ & 0.088 & can't reject & No causality \\
\hline $\begin{array}{l}\text { INFLATION (Y) does not Granger } \\
\text { Cause ALUMINIUM }\left(\mathrm{X}_{1}\right)\end{array}$ & 0.885 & can't reject & No causality \\
\hline $\begin{array}{l}\text { COPPER }\left(\mathrm{X}_{2}\right) \text { does not Granger } \\
\text { Cause INFLATION }(\mathrm{Y})\end{array}$ & 0.380 & can't reject & No causality \\
\hline $\begin{array}{l}\text { INFLATION }(\mathrm{Y}) \text { does not Granger } \\
\text { Cause COPPER }\left(\mathrm{X}_{2}\right)\end{array}$ & 0.086 & can't reject & No causality \\
\hline $\begin{array}{l}\text { NATURAL GAS }\left(\mathrm{X}_{3}\right) \text { does } \\
\text { Granger Cause INFLATION }(\mathrm{Y})\end{array}$ & 0.144 & can't reject & No causality \\
\hline $\begin{array}{l}\text { INFLATION (Y) does not Granger } \\
\text { Cause NATURAL GAS }\left(\mathrm{X}_{3}\right)\end{array}$ & 0.539 & can't reject & No causality \\
\hline $\begin{array}{l}\text { COAL }\left(\mathrm{X}_{4}\right) \text { does not Granger Cause } \\
\text { INFLATION }(\mathrm{Y})\end{array}$ & 0.304 & can't reject & No causality \\
\hline $\begin{array}{l}\text { INFLATION }(\mathrm{Y}) \text { does not Granger } \\
\text { Cause COAL }\left(\mathrm{X}_{4}\right)\end{array}$ & 0.728 & can't reject & No causality \\
\hline $\begin{array}{l}\text { OIL }\left(X_{5}\right) \text { does not Granger Cause } \\
\text { INFLATION }(Y)\end{array}$ & 0.311 & can't reject & No causality \\
\hline $\begin{array}{l}\text { INFLATION }(Y) \text { does not Granger } \\
\text { Cause OIL }\left(X_{5}\right)\end{array}$ & 0.072 & can't reject & No causality \\
\hline \multicolumn{4}{|l|}{ UK } \\
\hline Null Hypothesis $\left(\mathrm{H}_{0}\right)$ & p-value & Decision for $\mathrm{H}_{0}$ & Outcome \\
\hline $\begin{array}{l}\text { ALUMINIUM }\left(\mathrm{X}_{1}\right) \text { does not Granger } \\
\text { Cause INFLATION }(\mathrm{Y})\end{array}$ & 0.989 & can't reject & No causality \\
\hline $\begin{array}{l}\text { INFLATION }(Y) \text { does not Granger } \\
\text { Cause ALUMINIUM }\left(\mathrm{X}_{1}\right)\end{array}$ & 0.923 & can't reject & No causality \\
\hline $\begin{array}{l}\text { COPPER }\left(\mathrm{X}_{2}\right) \text { does not Granger } \\
\text { Cause INFLATION }(\mathrm{Y})\end{array}$ & 0.872 & can't reject & No causality \\
\hline $\begin{array}{l}\text { INFLATION (Y) does not Granger } \\
\text { Cause COPPER }\left(\mathrm{X}_{2}\right)\end{array}$ & 0.666 & can't reject & No causality \\
\hline $\begin{array}{l}\text { NATURAL GAS }\left(\mathrm{X}_{3}\right) \text { does } \\
\text { Granger Cause INFLATION }(\mathrm{Y})\end{array}$ & 0.002 & reject & Causality \\
\hline $\begin{array}{l}\text { INFLATION (Y) does not Granger } \\
\text { Cause NATURAL GAS }\left(\mathrm{X}_{3}\right)\end{array}$ & 0.913 & can't reject & No causality \\
\hline $\begin{array}{l}\text { COAL }\left(\mathrm{X}_{4}\right) \text { does not Granger Cause } \\
\text { INFLATION }(\mathrm{Y})\end{array}$ & 0.828 & can't reject & No causality \\
\hline $\begin{array}{l}\text { INFLATION }(\mathrm{Y}) \text { does not Granger } \\
\text { Cause COAL }\left(\mathrm{X}_{4}\right)\end{array}$ & 0.511 & can't reject & No causality \\
\hline $\begin{array}{l}\text { OIL }\left(X_{5}\right) \text { does not Granger Cause } \\
\text { INFLATION }(Y)\end{array}$ & 0.186 & can't reject & No causality \\
\hline $\begin{array}{l}\text { INFLATION }(Y) \text { does not Granger } \\
\text { Cause OIL }\left(X_{5}\right)\end{array}$ & 0.725 & can't reject & No causality \\
\hline \multicolumn{4}{|l|}{ Romania } \\
\hline Null Hypothesis $\left(\mathrm{H}_{0}\right)$ & $p$-value & Decision for $\mathrm{H}_{0}$ & Outcome \\
\hline $\begin{array}{l}\text { ALUMINIUM }\left(\mathrm{X}_{1}\right) \text { does not Granger } \\
\text { Cause INFLATION }(\mathrm{Y})\end{array}$ & 0.841 & can't reject & No causality \\
\hline $\begin{array}{l}\text { INFLATION (Y) does not Granger } \\
\text { Cause ALUMINIUM }\left(\mathrm{X}_{1}\right)\end{array}$ & 0.526 & can't reject & No causality \\
\hline $\begin{array}{l}\text { COPPER }\left(\mathrm{X}_{2}\right) \text { does not Granger } \\
\text { Cause INFLATION }(\mathrm{Y})\end{array}$ & 0.737 & can't reject & No causality \\
\hline $\begin{array}{l}\text { INFLATION (Y) does not Granger } \\
\text { Cause COPPER }\left(\mathrm{X}_{2}\right)\end{array}$ & 0.481 & can't reject & No causality \\
\hline
\end{tabular}




\begin{tabular}{|c|c|c|c|}
\hline $\begin{array}{l}\text { Granger Cause INFLATION }(\mathrm{Y}) \\
\text { INFLATION }(\mathrm{Y}) \text { does not Granger } \\
\text { Cause NATURAL GAS }\left(\mathrm{X}_{3}\right)\end{array}$ & 0.963 & can't reject & No causality \\
\hline $\begin{array}{l}\text { COAL }\left(\mathrm{X}_{4}\right) \text { does not Granger Cause } \\
\text { INFLATION }(\mathrm{Y})\end{array}$ & 0.507 & can't reject & No causality \\
\hline $\begin{array}{l}\text { INFLATION }(\mathrm{Y}) \text { does not Granger } \\
\text { Cause COAL }\left(\mathrm{X}_{4}\right)\end{array}$ & 0.989 & can't reject & No causality \\
\hline $\begin{array}{l}\text { OIL (X5) does not Granger Cause } \\
\text { INFLATION (Y) }\end{array}$ & 0.857 & can't reject & No causality \\
\hline $\begin{array}{l}\text { INFLATION }(Y) \text { does not Granger } \\
\text { Cause OIL }\left(X_{5}\right)\end{array}$ & 0.984 & can't reject & No causality \\
\hline \multicolumn{4}{|l|}{ Slovakia } \\
\hline Null Hypothesis $\left(\mathrm{H}_{0}\right)$ & $p$-value & Decision for $\mathrm{H}_{0}$ & Outcome \\
\hline $\begin{array}{l}\text { ALUMINIUM }\left(\mathrm{X}_{1}\right) \text { does not Granger } \\
\text { Cause INFLATION }(\mathrm{Y})\end{array}$ & 0.968 & can't reject & No causality \\
\hline $\begin{array}{l}\text { INFLATION (Y) does not Granger } \\
\text { Cause ALUMINIUM }\left(\mathrm{X}_{1}\right)\end{array}$ & 0.376 & can't reject & No causality \\
\hline $\begin{array}{l}\text { COPPER }\left(\mathrm{X}_{2}\right) \text { does not Granger } \\
\text { Cause INFLATION }(\mathrm{Y})\end{array}$ & 0.301 & can't reject & No causality \\
\hline $\begin{array}{l}\text { INFLATION }(\mathrm{Y}) \text { does not Granger } \\
\text { Cause COPPER }\left(\mathrm{X}_{2}\right)\end{array}$ & 0.327 & can't reject & No causality \\
\hline $\begin{array}{lrrr}\text { NATURAL GAS }\left(\mathrm{X}_{3}\right) & \text { does } & \text { not } \\
\text { Granger Cause INFLATION }(\mathrm{Y}) & \end{array}$ & 0.324 & can't reject & No causality \\
\hline $\begin{array}{l}\text { INFLATION (Y) does not Granger } \\
\text { Cause NATURAL GAS }\left(\mathrm{X}_{3}\right)\end{array}$ & 0.107 & can't reject & No causality \\
\hline $\begin{array}{l}\text { COAL }\left(\mathrm{X}_{4}\right) \text { does not Granger Cause } \\
\text { INFLATION }(\mathrm{Y})\end{array}$ & 0.923 & can't reject & No causality \\
\hline $\begin{array}{l}\text { INFLATION }(Y) \text { does not Granger } \\
\text { Cause COAL }\left(\mathrm{X}_{4}\right)\end{array}$ & 0.950 & can't reject & No causality \\
\hline $\begin{array}{l}\text { OIL }\left(X_{5}\right) \text { does not Granger Cause } \\
\text { INFLATION }(Y)\end{array}$ & 0.438 & can't reject & No causality \\
\hline $\begin{array}{l}\text { INFLATION }(Y) \text { does not Granger } \\
\text { Cause OIL }\left(X_{5}\right)\end{array}$ & 0.753 & can't reject & No causality \\
\hline \multicolumn{4}{|l|}{ Slovenia } \\
\hline Null Hypothesis $\left(\mathrm{H}_{0}\right)$ & p-value & Decision for $\mathrm{H}_{0}$ & Outcome \\
\hline $\begin{array}{l}\text { ALUMINIUM }\left(\mathrm{X}_{1}\right) \text { does not Granger } \\
\text { Cause INFLATION }(\mathrm{Y})\end{array}$ & 0.053 & can't reject & No causality \\
\hline $\begin{array}{l}\text { INFLATION }(Y) \text { does not Granger } \\
\text { Cause ALUMINIUM }\left(X_{1}\right)\end{array}$ & 0.511 & can't reject & No causality \\
\hline $\begin{array}{l}\text { COPPER }\left(\mathrm{X}_{2}\right) \text { does not Granger } \\
\text { Cause INFLATION }(\mathrm{Y})\end{array}$ & 0.156 & can't reject & No causality \\
\hline $\begin{array}{l}\text { INFLATION (Y) does not Granger } \\
\text { Cause COPPER }\left(\mathrm{X}_{2}\right)\end{array}$ & 0.052 & can't reject & No causality \\
\hline $\begin{array}{l}\text { NATURAL GAS }\left(\mathrm{X}_{3}\right) \text { does } \\
\text { Granger Cause INFLATION }(\mathrm{Y})\end{array}$ & 0.245 & can't reject & No causality \\
\hline $\begin{array}{l}\text { INFLATION (Y) does not Granger } \\
\text { Cause NATURAL GAS }\left(\mathrm{X}_{3}\right)\end{array}$ & 0.847 & can't reject & No causality \\
\hline $\begin{array}{l}\text { COAL }\left(\mathrm{X}_{4}\right) \text { does not Granger Cause } \\
\text { INFLATION }(\mathrm{Y})\end{array}$ & 0.322 & can't reject & No causality \\
\hline $\begin{array}{l}\text { INFLATION }(\mathrm{Y}) \text { does not Granger } \\
\text { Cause COAL }\left(\mathrm{X}_{4}\right)\end{array}$ & 0.714 & can't reject & No causality \\
\hline $\begin{array}{l}\text { OIL }\left(X_{5}\right) \text { does not Granger Cause } \\
\text { INFLATION }(Y)\end{array}$ & 0.784 & can't reject & No causality \\
\hline $\begin{array}{l}\text { INFLATION }(Y) \text { does not Granger } \\
\text { Cause OIL }\left(X_{5}\right)\end{array}$ & 0.594 & can't reject & No causality \\
\hline
\end{tabular}

Source: authors 